\title{
Multiple Organ Failure
}

National Cancer Institute

\section{Source}

National Cancer Institute. Multiple Organ Failure. NCI Thesaurus. Code C75568.

Complete impairment of two or more organs or organ systems. 